\title{
Tingkat Kesukaan Konsumen Terhadap Telur Asin Ayam Ras dan Telur Asin Itik Di Kecamatan Kembangbahu, Kabupaten Lamongan
}

\author{
Muridi Qomaruddin* dan Hilal Afandi* \\ * Program Studi Peternakan Fakultas Peternakan Universitas Islam Lamongan \\ Jl.Veteran No.53.A Lamongan
}

\begin{abstract}
Pengumpulan data ini dilaksanakan di bulan Maret 2017 di Kecamatan Kembangbahu, Kabupaten Lamongan. Sedangkan penelitian dilaksanakan di UPT Agri Science Technopark Universitas Islam Lamongan. Tujuan dari penelitian ini adalah untuk mengetahui tingkat kesukaan konsumen terhadap telur asin ayam ras dan telur asin itik di Kecamatan Kembangbahu Kabupaten Lamongan. Kegunaan dari penelitian ini diharapkan agar digunakan sebagai bahan penelitian untuk meningkatkan pengetahuan, wawasan dan pengalaman dalam bidang survei tingkat kesukaan konsumen telur asin ayam ras dan telur asin itik. Materi yang digunakan dalam penelitian ini adalah 20 butir telur ayam ras, 20 butir telur itik, garam $2 \mathrm{~kg}$, batu bata $4 \mathrm{~kg}$ dan air. Metode pemeraman telur asin menggunakan media batu bata dan garam, dengan perbandingan batu bata $4 \mathrm{~kg}$ dan garam $1 \mathrm{~kg}$. Pemeraman telur ayam dilakukan 7 hari dan telur itik dilakukan 9 hari. Variabel yang diamati dalam penelitian ini adalah uji kadar kemasiran, uji kadar air dan uji organoleptik. Data hasil uji organoleptik dianalisis menggunakan analisis statisti Uji-T Independen. Hasil penelitian yang diteliti dapat disimpulkan bahwasannya dari segi kemasiran telur asin ayam ras menghasilkan kemasiran kuning telur sebesar 0,92\% sedangkan telur asin itik menghasilkan kemasiran kuning telur sebesar $0,91 \%$. Nilai penurunan kadar air putih telur tertinggi terjadi pada putih telur itik sebesar 13,89 g dan nilai penurunan kadar air kuning telur tertinggi terjadi pada kuning telur itik sebesar 4,67 g. Untuk parameter Tingkat kesukaan konsumen terhadap telur asin ayam ras dan telur asin itik di Kecamatan Kembangbahu, Kabupaten Lamongan dari parameter rasa, warna, aroma/bau dan tekstur memberikan perbedaan yang nyata $\left(T_{\text {hitung }} \geq 0,5\right.$ ). Dari uji organoleptik (rasa, aroma/bau, warna dan tekstur) telur asin ayam ras lebih disukai dibandingkan telur asin itik.
\end{abstract}

KATA KUNCI : Telur Asin, Telur Asin ayam, Konsumen.

\section{PENDAHULUAN}

Telur merupakan salah satu bahan pangan hasil ternak yang bergizi tinggi dan sangat dibutuhkan oleh tubuh, karena merupakan sumber protein, asam lemak, vitamin, dan mineral. Selain itu, telur mudah didapatkan dan harganya terjangkau. Ada bermacam-macam jenis telur yang umum dikonsumsi, diantaranya telur ayam dan telur itik. Namun, disamping adanya hal-hal yang menguntungkan itu, telur memiliki sifat yang mudah rusak, maka perlu usaha pengolahan ataupun pengawetan yang dapat mempertahankan kualitas dan memperpanjang masa simpan telur. Salah satu upaya untuk mengawetkan telur, menjaga telur itu supaya tidak rusak dan memperpanjang masa simpannya adalah dengan cara pengasinan atau diolah menjadi telur asin. Cara pembuatan telur asin dapat menggunakan beberapa metode salah satunya dengan melumuri telur menggunakan media yang berupa campuran garam dengan batu bata.

Pengasinan telur merupakan salah satu upaya untuk mengawetkan telur segar, memperpanjang masa simpan, membuang bau amis telur serta menciptakan rasa yang khas (Astawan dan Astawan, (1989) dalam Lukito, (2012)). Proses pembuatan telur asin yang telah banyak dilakukan oleh masyarakat adalah dengan menggunakan batu bata merah yang dicampur dengan garam, setelah itu dibersihkan (dicuci) dan direbus (Sarwono, (1995) dalam Lukito, (2012)). Menurut Samosir (1983) dalam Lukito (2012), lama pemeraman telur akan mempengaruhi tingkat keasinan dari telur asin tersebut.

Suatu produk pangan harus disukai oleh konsumen, dan untuk mengetahuinya maka dilakukan pengujian. Pada uji tingkat kesukaan panelis diminta mengungkapkan tanggapan pribadinya tentang kesukaan atau sebaliknya ketidaksukaan. Tingkat kesukaan ini sering disebut orang sebagai skala hedonik, misalnya amat sangat suka, sangat suka, agak suka, suka, netral, agak tidak suka, sangat tidak suka dan amat sangat tidak suka (Rahayu, (1998) dalam Sukma, (2012)). Uji kesukaan perlu dilakukan untuk mengetahui sejauh mana daya terima dari konsumen terhadap suatu produk dan uji ini berkaitan 
dengan eksistensi produk dan daya terima dari konsumen terhadap suatu produk (Hui, (1993) dalam Sukma, (2012)).

Berdasarkan data Badan Statistika Kabupaten Lamongan (2017), produksi telur di Kecamatan Kembangbahu menempati posisi ke 18 dengan produksi telur sebesar $521.270 \mathrm{~kg}$ dalam 5 tahun terakhir.

Masyarakat hanya mengetahui telur asin yang terbuat dari telur itik, padahal telur ayam pun juga bisa dijadikan sebagai telur asin. Selain mudah didapatkan dan harganya lebih murah, telur ayam mempunyai kadar kolestrol yakni berkisar $423,00 \mathrm{mg}$ lebih rendah dari telur itik yang kandungan kolestrolnya sebesar 884,00 mg (USDA, (2007) dalam Sukma, (2012)). Dari latar belakang tersebut, maka penulis ingin mengetahui tingkat kesukaan konsumen terhadap telur asin itik dan telur asin ayam di Kecamatan Kembangbahu Kabupaten Lamongan.

\section{MATERI DAN METODE}

\section{Materi Penelitian}

Penelitian ini menggunakan telur ayam ras 40 butir dan telur itik 40 butir. Kemudian untuk adonan untuk membuat telur asin digunakan bubuk bata dan garam dapur dengan perbandingan adonan 4:1 yaitu $4000 \mathrm{gr}$ bubuk batu bata, 1000 gram garam dan air sebanyak $2500 \mathrm{ml}$.

\section{METODE PENELITIAN}

Metode Penelitian ini adalah metode experimental untuk pembuatan telur asin, kadar air telur asin dan kemasiran telur asin. Sedangkan tingkat kesukaan menggunakan metode non eksperimental, yakni dengan mengambil data kuisioner dari panelis.

\section{VARIABEL YANG DIAMATI}

Variable yang diukur dalam penelitian ini adalah :

1. Uji kualitas fisik yang meliputi : kadar air telur asin dan kemasiran kuning telur.

2. Uji organoleptik meliputi warna, aroma/bau, rasa, dan tekstur.

Model matematika yang digunakan dalam penelitian ini adalah :

1. Kemasiran

$$
\% \text { Permukaan yang berminyak }(Y)=\frac{m \mathrm{~cm}^{2}}{t \mathrm{~cm}^{2}} \times 100 \%
$$

2. Kadar air

Kadar Air $=\frac{\text { Bobot sampel awal }- \text { bobot sampel akhir }}{\text { Bobot sampel awal }} \times 100 \%$

3. Uji Organoleptik

Uji organoleptik menggunakan rumus Uji T Independent sebagai berikut:

$$
\text { Thitung }=\frac{x_{1}-x_{2}}{\sqrt{\frac{S_{1}^{2}}{n_{1}}}+\sqrt{\frac{S_{2}^{2}}{n_{2}}}}
$$

\section{Waktu dan Lokasi Penelitian}

Penelitian ini dilaksanakan pada tanggal 12 Maret sampai 20 Maret 2017. Pengumpulan data primer dilaksanakan di Kecamatan Kembangbahu, Kabupaten Lamongan. Sedangkan penelitian dilaksanakan di UPT Agri Science Technopark Universitas Islam Lamongan.

HASIL DAN PEMBAHASAN

\section{Uji Kadar Kemasiran Telur Asin}


Sifat fisik telur asin yang diamati dalam penelitian ini adalah tingkat kemasiran kuning telur. Besarnya tingkat kemasiran kuning telur asin ayam ras dan itik (setelah direbus) dari hasil penelitian ini disajikan dalam Tabel 4.1.

Tabel 4.1 Tingkat Kemasiran Kuning Telur Asin Ayam Ras dan Telur Asin Itik (\%).

\begin{tabular}{|c|c|}
\hline Jenis Telur Asin & $\begin{array}{c}\text { \% Permukaan Kuning } \\
\text { Telur yang berminyak }\end{array}$ \\
\hline Telur Asin Ayam Ras & 92,8 \\
\hline Telur Asin Itik & 93,3 \\
\hline \multicolumn{2}{|c|}{ Sumber : Data Primer yang Telah Diolah (2017) }
\end{tabular}

Berdasarkan hasil penelitian diatas dapat diketahui bahwa telur asin ayam ras menghasilkan kemasiran kuning telur sebesar 92,8\% sedangkan telur asin itik menghasilkan kemasiran kuning telur sebesar 93,3\%. Menurut Chi dan Tseng (1998) dalam Utomo (2006) tekstur masir ini terjadi karena garam masuk bersama air ke dalam granul-granul yang berada dalam kuning telur. Garam tersebut akan merusak ikatan LDL (Low Dencity Lipoprotein) sebagai penyusun terbesar granul. Kerusakan ikatan LDL (Low Dencity Lipoprotein) ini akan memperbesar diameter dari granula. Semakin sedikit air yang masuk dalam granul maka batas antara granul dalam kuning telur semakin tampak.

Sebagian besar kandungan kuning telur adalah protein dan lemak. Kedua zat tersebut membentuk ikatan lipoprotein. Sekitar 96\% dari padatan kuning telur adalah lipoprotein (Chang dkk., (1977) dalam Rukmiasih, (2015)). Permeraman telur itik dan telur ayam dengan menggunakan media batu bata dan garam akan menyebabkan terjadinya difusi garam $\mathrm{NaCl}$ ke dalam telur melalui pori-pori kerabang menuju bagian putih hingga bagian kuning telur. Adanya difusi ion-ion $\mathrm{Na}+$ dan $\mathrm{Cl}$ - ini menyebabkan kerusakan ikatan lipoprotein (Stadelman dan Cotterill (1995) dalam Rukmiasih, (2015)).

Semakin banyak konsentrasi $\mathrm{NaCl}$ yang masuk ke dalam kuning telur maka akan melepas ikatan lipoprotein (senyawa kompleks antara lemak dan protein) didalam padatan kuning telur. Lepasnya ikatan lipoprotein ini menyebabkan lemak terpisah dari protein. Hal tersebut berakibat menyatunya proteinprotein kuning telur, kemudian membentuk padatan atau granul polihedral yang semakin membesar. Hal inilah yang menimbulkan tekstur masir (Chi dan Tseng (1998) dalam Rukmiasih, (2015)).

\section{Uji Kadar Air Telur Asin}

Hasil analisis kimia mengenai kadar air telur asin ayam ras dan telur asin itik yang dipisahkan antara putih telur dan kuning telurnya disajikan pada Tabel 4.2.

Tabel 4.2 Nilai Kadar Air pada Putih dan Kuning Telur Asin Ayam Ras dan Telur Asin Itik (\%).

\begin{tabular}{|c|c|c|}
\hline \multirow{2}{*}{ Jenis Telur Asin } & \multicolumn{2}{|c|}{ Kadar Air dalam \% } \\
\cline { 2 - 3 } & Putih Telur & Kuning Telur \\
\hline Telur Ayam Ras & $13,44 \pm 0,1000$ & $3,36 \pm 0,011$ \\
\hline Telur Itik & $13,89 \pm 0,0057$ & $4,67 \pm 4,806$ \\
\hline
\end{tabular}

Sumber : Data Primer yang Telah Diolah (2017)

Hasil analisis kadar air telur asin dalam penelitian ini disajikan dalam Tabel 4.2 diatas. Pada penelitian ini, setelah telur diasinkan dengan media yang sama, secara umum kadar airnya menurun, menjadi sekitar 13,44 \% (pada putih telur ayam ras), 13,89 \% (pada putih telur itik), 3,36 \% (pada kuning telur ayam ras) dan 4,67\% (pada kuning telur itik). Penurunan ini disebabkan adanya difusi larutan garam $\mathrm{NaCl}$ ke dalam telur, sehingga menyebabkan keluarnya air dari dalam telur (Sipan dan Winarto, (2007) dalam Rukmiasih, (2015)). Pengeluaran air ini berlangsung secara terus menerus sampai tercapainya suatu keseimbangan konsentrasi larutan (isotonis) (Heath, (1977) dalam Rukmiasih, (2015)).

Penurunan kadar air pada putih telur asin lebih tinggi dibandingkan pada kuning telur. Nilai penurunan kadar air putih telur tertinggi terjadi pada putih telur itik. Hal ini berarti bahwa ion-ion dari garam $\mathrm{NaCl}$ mencapai putih telur itik lebih banyak dan lebih cepat. Sebagai akibat dari peristiwa ini adalah keluarnya air dari putih telur juga lebih banyak.

Kadar air kuning telur setelah diasinkan mengalami penurunan sebesar 3,36\% (kuning telur ayam ras) dan 4,67\% (kuning telur itik). Penurunan tersebut disebabkan oleh keluarnya air dari kuning telur ke putih telur. Menurut Lai dkk., (1999) dalam Utomo (2006), keluarnya air dari kuning telur ke putih telur 
disebabkan karena peningkatan kadar garam di putih telur lebih cepat dibandingkan peningkatan kadar garam di kuning telur. Shenstone (1968) dalam Utomo (2006), menambahkan bahwa lambatnya laju difusi garam ke kuning telur disebabkan karena sebagian besar komponen kuning telur adalah lemak.

\section{Uji Organoleptik (Kualitas Sensori)}

Uji organoleptik memiliki arti yang sangat penting untuk suatu produk pangan yang berkaitan dengan penerimaan konsumen terhadap produk yang dihasilkan. Meskipun dari segi nutrisi sudah terpenuhi namun apabila dari segi sensori kurang disukai, maka pengembangan untuk produk pangan tersebut akan sulit dan tidak sesuai dengan tujuan yang diharapkan. Dalam penelitian ini dilakukan uji organoleptik terhadap produk olahan telur asin ayam ras dan telur asin itik. Pengujian organoleptik telur asin ayam ras dan telur asin itik dilakukan terhadap 30 orang panelis konsumen di Kecamatan Kembangbahu, Kabupaten Lamongan. Skor kesukaan mulai dari nilai (1) sangat tidak suka; (2) tidak suka; (3) agak tidak suka; (4) netral; (5) agak suka; (6) suka dan (7) sangat suka dengan parameter yang diuji meliputi warna, aroma, rasa, dan tekstur.

\section{Warna}

Selain untuk selera, warna dalam suatu produk khususnya produk makanan memegang peranan penting dalam daya terima konsumen. Apabila suatu produk memiliki warna yang menarik maka dapat meningkatkan selera konsumen untuk mencoba makanan tersebut. Setyaningsih (2008) dalam Lesmayati (2014) menambahkan bahwa warna menjadi atribut kualitas yang paling penting, walaupun suatu produk pangan bernilai gizi tinggi, rasa enak dan tekstur baik, namun apabila warna yang ditampilkan kurang menarik maka akan menyebabkan produk pangan kurang diminati oleh konsumen. Pengujian dengan indera penglihat masih sangat menentukan dalam pengujian sensoris warna pada produk pangan (Putri, 2011). Hasil uji organoleptik tingkat kesukaan untuk parameter warna telur asin ayam ras dan telur asin itik baik pada bagian putih telur maupun kuning telur dapat dilihat pada Gambar 8.

Gambar 8. Hasil Organoleptik Tingkat Kesukaan untuk Parameter Warna Telur Asin Ayam Ras dan Telur Asin Itik.

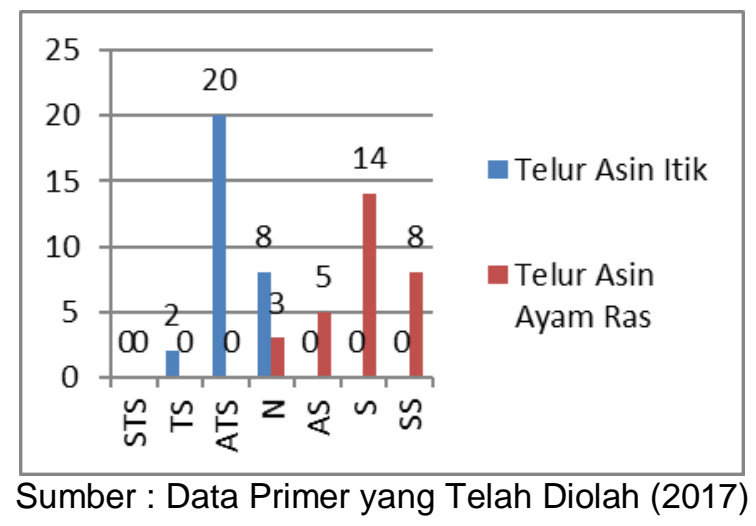

Dari Gambar 8 diatas dapat dilihat bahwa dari segi warna telur asin itik tidak disukai dengan panelis yang memilih poin Agak Tidak Suka (ATS) sebanyak 20 orang dan telur asin ayam ras lebih disukai dengan panelis yang memilih poin Suka (S) sebanyak 14 orang. Hasil analisis statistika uji-T Independen terhadap karakteristik warna pada telur asin ayam ras dan telur asin itik dapat disajikan pada Tabel 4.3.

Tabel 4.3 Hasil Analisis Statistika Uji-T Independen Terhadap Karakteristik Warna Telur Asin Ayam Ras dan Telur Asin Itik.

\begin{tabular}{|c|c|c|c|c|c|c|}
\hline Jenis Telur & Mean & SD & Varians & Korelasi & $T_{\text {Hitung }}$ & $\mathrm{T}_{\text {Tabel }}$ 5\% \\
\hline $\begin{array}{l}\text { Telur Asin } \\
\text { Ayam }\end{array}$ & 5,9 & 0,92 & 0,8 & \multirow[b]{2}{*}{0,873} & \multirow[b]{2}{*}{$13,7^{*}$} & \multirow[b]{2}{*}{2,004} \\
\hline $\begin{array}{l}\text { Telur Asin } \\
\text { Itik }\end{array}$ & 3,2 & 0,55 & 0,3 & & & \\
\hline
\end{tabular}




\section{Sumber : Data Primer yang Telah Diolah (2017)}

Berdasarkan analisis statistika dalam Tabel 4.3 diatas dapat diketahui bahwa hasil uji-T Independen telur asin ayam ras dan telur asin itik adalah berbeda nyata artinya telur asin ayam lebih disukai dari pada telur asin itik dari segi warna. Hal ini disebabkan karena warna pada kuning telur asin ayam berwarna orange cerah lebih menarik dibandingkan dengan telur asin itik yang warna kuning telurnya hitam kehijauan sehingga panelis lebih menyukai telur asin itik dibandingkan telur asin ayam. Menurut Masykuroh (2016) warna kuning telur yang baik adalah kuning telur yang bersih tanpa adanya noda. Winarno dan Koswara (2002) dalam Masykuroh (2016) menambahkan bahwa perubahan warna kuning pada kuning telur olahan menjadi warna hitam kehijauan disebabkan oleh pemanasan yang terlalu lama sehingga membentuk Fe dan S.

Warna kuning telur sebelum diasinkan adalah kuning, warna akan berubah menjadi kuning kecokelatan, cokelat tua, orange, atau kuning cerah setelah melalui proses pengasinan. Perubahan warna kuning tersebut berhubungan dengan hilangnya air dan sejumlah lemak yang menjadi bebas dari kuning telur. Kadar air mempengaruhi konsentrasi pigmen (Oktaviani, (2012) dalam Masykuroh (2016)).

\section{Aroma/ bau}

Aroma adalah bau yang dapat diamati dengan indera pembau (hidung). Pengujian aroma atau bau adalah salah satu pengujian yang penting karena dapat memberikan hasil penilaian terhadap daya terima produk (Kartika, dkk., (1988) dalam Lesmayati, (2014)). Aroma dapat digunakan sebagai indikator terjadinya kerusakan pada olahan produk pangan. Telur asin yang sudah tidak layak dikonsumsi akan berbau sangat menyengat/busuk.

Aroma memiliki fungsi yang penting dalam olahan produk pangan, karena sebelum mengkonsumsi biasanya terlebih dahulu aroma makanan akan tercium oleh indera penciuman (hidung), apabila aroma pada produk terlalu menyengat atau terkesan hambar akan membuat konsumen tidak tertarik untuk mengkonsumsinya. Hasil uji sensoris tingkat kesukaan untuk parameter aroma/bau telur asin ayam ras dan telur asin itik baik pada bagian putih telur maupun kuning telur dapat dilihat pada Gambar 9.

Gambar 9 Hasil Organoleptik Tingkat Kesukaan untuk Parameter Aroma/Bau Telur Asin Ayam Ras dan Telur Asin Itik.

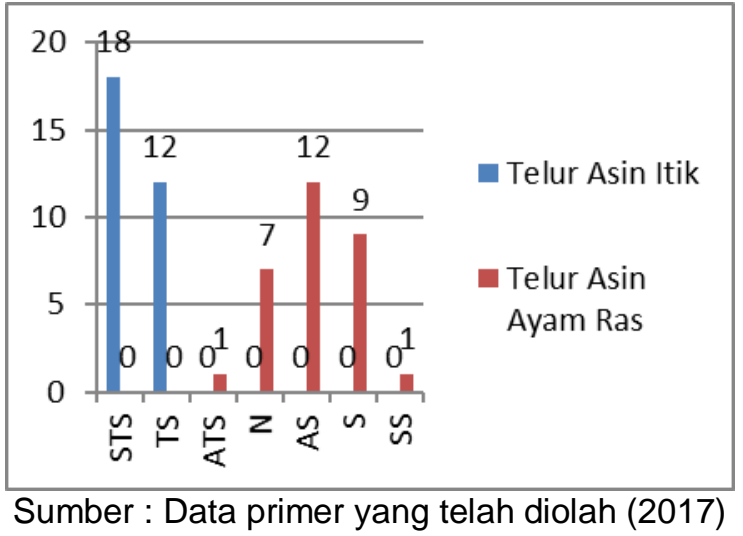

Dari Gambar 9 diatas dapat diketahui bahwa dari segi aroma/bau telur asin itik sangat tidak disukai dengan panelis yang memilih poin Sangat Tidak Suka (STS) sebanyak 18 orang dan telur asin ayam ras lebih disukai dengan panelis yang memilih poin Agak Suka (S) sebanyak 12 orang. Hasil analisis statistika uji-T Independen terhadap karakteristik aroma/bau pada telur asin ayam ras dan telur asin itik dapat disajikan pada Tabel 4.4.

Tabel 4.4 Hasil Analisis Statistika Uji-T Independen Terhadap Karakteristik Aroma/Bau Telur Asin Ayam Ras dan Telur Asin Itik.

\begin{tabular}{|l|l|c|c|c|c|c|}
\hline Jenis Telur & Mean & SD & Varians & Korelasi & THitung & $\begin{array}{c}\text { TTabel } \\
5 \%\end{array}$ \\
\hline $\begin{array}{l}\text { Telur Asin } \\
\text { Ayam }\end{array}$ & 5,06 & 0,9 & 0,8 & 0,78 & $\begin{array}{c}19,40 \\
4^{*}\end{array}$ & 2,004 \\
\hline
\end{tabular}




\begin{tabular}{|l|l|c|c|c|c|c|}
\hline Telur Asin Itik & 1,4 & 0,4 & 0,2 & & & \\
\hline \multicolumn{7}{|c|}{ Keterangan : ${ }^{*}$ Berbeda Nyata }
\end{tabular}

Sumber : Data Primer yang Telah Diolah (2017)

Berdasarkan analisis statistika dalam Tabel 4.4 diatas dapat diketahui bahwa hasil uji-T Independen untuk karakteristik aroma/bau telur asin ayam ras dan telur asin itik adalah berbeda nyata artinya telur asin ayam lebih disukai dari pada telur asin itik dari segi aroma/bau. Hal ini kemungkinan disebabkan bau amis pada telur itik masih berbau amis, dikarenakan pemeraman telur itik hanya 9 hari saja. Berdasarkan hasil penelitian yang dilakukan oleh Lesmayati (2014) didapatkan hasil bahwa telur itik dengan pemeraman 20 hari dapat mengurangi bau amis yg terdapat pada telur, semakin lama telur diperam pada adonan garam dan batu bata maka bau amis pada telur asin dapat berkurang.

Masykuroh (2016) menambahkan bahwa aroma yang baik dari telur asin adalah tidak bau amoniak, tidak bau busuk, dan tidak bau lainnya yang tidak diharapkan. Bau busuk terbentuk dari senyawasenyarwa seperti amonia, $\mathrm{H}_{2} \mathrm{~S}$, indol, dan amin yang merupakan hasil pemecahan protein oleh mikroorganisme.

\section{Rasa}

Rasa merupakan salah satu faktor penting dalam produk pangan. Rasa telur asin umumnya terasa asin, sesuai dengan tingkat pemberian garam dalam pembuatan telur asin dan juga lama pemeraman. Hasil uji sensoris tingkat kesukaan untuk parameter rasa telur asin ayam ras dan telur asin itik baik pada bagian putih telur maupun kuning telur dapat dilihat pada Gambar 10.

Gambar 10 Hasil Organoleptik Tingkat Kesukaan untuk Parameter Rasa Telur Asin Ayam Ras dan Telur Asin Itik.

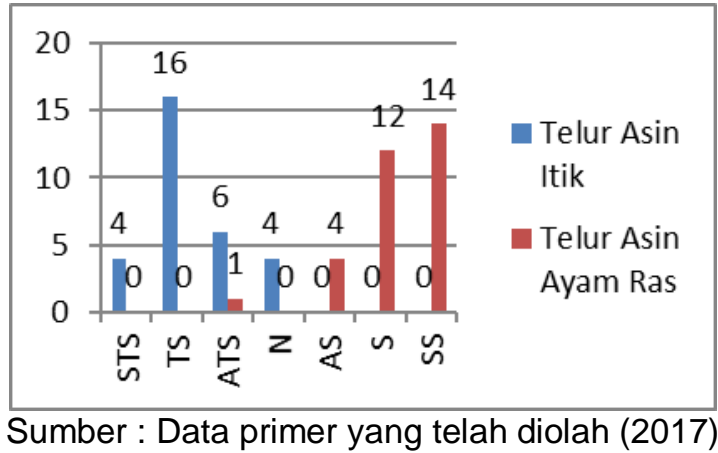

Dari Gambar 10 diatas dapat diketahui bahwa dari segi rasa telur asin itik tidak disukai dengan panelis yang memilih poin Tidak Suka (TS) sebanyak 16 orang dan telur asin ayam ras lebih disukai dengan panelis yang memilih poin Sangat Suka (SS) sebanyak 14 orang. Hasil analisis statistika uji-T Independen terhadap karakteristik rasa pada telur asin ayam ras dan telur asin itik dapat disajikan pada Tabel 4.5.

Tabel 4.5 Hasil Analisis Statistika Uji-T Independen Terhadap Karakteristik Rasa Telur Asin Ayam Ras dan Telur Asin Itik.

\begin{tabular}{|l|l|c|c|c|c|c|}
\hline \multicolumn{1}{|c|}{ Jenis Telur } & Mean & SD & Varians & Korelasi & $T_{\text {Hitung }}$ & $\begin{array}{c}T_{\text {Tabel }} \\
5 \%\end{array}$ \\
\cline { 1 - 5 } $\begin{array}{l}\text { Telur Asin } \\
\text { Ayam }\end{array}$ & 6,2 & 0,92 & 0,8 & \multirow{2}{*}{0,76} & $16,554^{*}$ & 2,004 \\
\hline Telur Asin Itik & 2,3 & 0,89 & 0,7 & & \\
\hline
\end{tabular}

Keterangan : *Berbeda Nyata

Sumber : Data Primer yang Telah Diolah (2017)

Berdasarkan analisis statistika dalam Tabel 4.5 diatas dapat diketahui bahwa hasil uji-T Independen telur asin ayam ras dan telur asin itik adalah berbeda nyata artinya telur asin ayam lebih disukai dari pada telur asin itik dari segi rasa. Hal ini disebabkan karena telur asin ayam kadar airnya terendah sehingga telur memiliki cita rasa yang lebih enak dan rasa masir atau berpasir kuning telur yang semakin meningkat. Hasil penelitian Wulandari dkk., (2002) rasa masir dari kuning telur dipengaruhi oleh besaran 
minyak yang keluar, kekuatan gel dari kunig telur dan diameter granula kuning telur. Semakin tinggi nilai ketiga kriteria mutu tersebut, rasa masir kuning telur yang dihasilkan semakin tinggi. Djaafar (2007) dalam Novia (2011) menambahkan lemak dalam telur berfungsi meningkatkan cita rasa. Kemudian hasil penelitian Zulaekah dan Widyaningsih (2005) bahwa ekstrak teh yang digunakan untuk merendam telur asin dapat memperbaiki cita rasa dari telur asin rebus.

\section{Tekstur}

Tekstur telur asin dipengaruhi oleh kadar air yaitu dimana berkurangnya kadar air menimbulkan tekstur telur asin yang semakin keras. Pada proses pengasinan kemampuan $\mathrm{NaCl}$ untuk mengikat air mempunyai afinitas yang lebih besar dari pada protein menyebabkan jarak antara molekul protein semakin dekat sehingga interaksi antara molekul protein semakin kuat. Ikatan yang kuat tersebut menyebabkan protein menggumpal sehingga menyebabkan tekstur protein semakin kenyal. Selain itu, tekstur putih telur dapat dipengaruhi oleh beberapa faktor yaitu kadar protein, suhu pemanasan, kekuatan ion dan adanya interaksi dengan komponen lain (Nurhidayat dkk., 2013). Budiman dkk., (2012), menambahkan bahwa tingkat kekenyalan yang cenderung semakin meningkat disebabkan karena pengaruh kadar air, kadar air yang sedikit akan menghasilkan tekstur yang kenyal.

Kemasiran telur asin dapat terjadi karena kemampuan $\mathrm{NaCl}$ untuk mengikat air mempunyai afinitas yang lebih besar dari pada protein menyebabkan ikatan antar molekul semakin kuat. lkatan yang kuat menyebabkan protein menggumpal. Pengumpalan protein dalam kuning telur menyebabkan tekstur berpasir (Nurhidayat dkk., (2013) dalam Nuruzzakia, (2016)). Tekstur masir dari kuning telur juga dipengaruhi oleh besaran minyak yang keluar, kekuatan gel dari kuning telur dan diameter granula kuning telur. Semakin tinggi nilai ketiga kriteria mutu tersebut, rasa masir kuning telur dihasilkan semakin tinggi (Novia dkk., (2011) dalam Nuruzzakia, (2016)).

Tekstur telur asin yang baik adalah apabila putih telurnya kenyal dan kuning telurnya masir. Hasil uji sensoris tingkat kesukaan untuk parameter tekstur telur asin ayam ras dan telur asin itik baik pada bagian putih telur maupun kuning telur dapat dilihat pada Gambar 11.

Gambar 11 Hasil Organoleptik Tingkat Kesukaan untuk Parameter Tekstur Telur Asin Ayam Ras dan Telur Asin Itik.

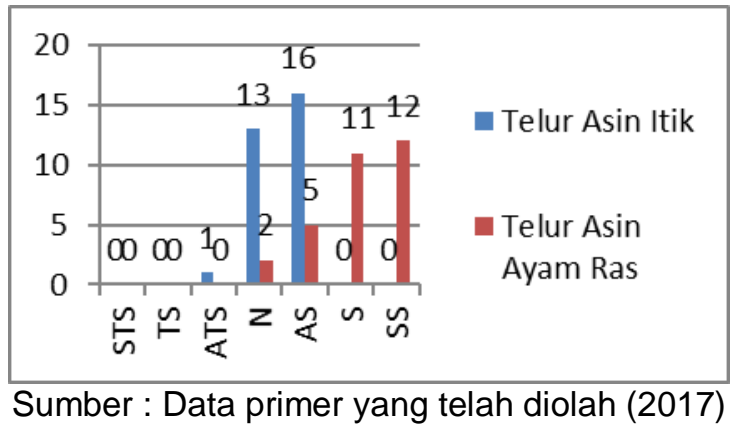

Dari Gambar 11 diatas dapat diketahui bahwa dari segi tekstur telur asin itik agak disukai dengan panelis yang memilih poin Agak Suka (AS) sebanyak 16 orang dan telur asin ayam ras sangat disukai dengan panelis yang memilih poin Sangat Suka (SS) sebanyak 12 orang. Hasil analisis statistika uji-T Independen terhadap karakteristik tekstur pada telur asin ayam ras dan telur asin itik dapat disajikan pada Tabel 4.6.

Tabel 4.6 Hasil Analisis Statistika Uji-T Independen Terhadap Karakteristik Tekstur Telur Asin Ayam Ras dan Telur Asin Itik.

\begin{tabular}{|l|l|c|c|c|c|c|}
\hline Jenis Telur & Mean & SD & Varians & Korelasi & THitung & $\begin{array}{c}\text { Tabel } \\
5 \%\end{array}$ \\
\hline $\begin{array}{l}\text { Telur Asin } \\
\text { Ayam }\end{array}$ & 6,1 & 0,9 & 0,8 & \multirow{2}{*}{0,816} & $8,070^{*}$ & 2,004 \\
\hline Telur Asin Itik & 4,5 & 0,6 & 0,3 & & & \\
\hline
\end{tabular}

Keterangan : *Berbeda Nyata

Sumber : Data Primer yang Telah Diolah (2017) 
Berdasarkan analisis statistika dalam Tabel 4.6 diatas dapat diketahui bahwa hasil uji-T Independen untuk karakteristik tekstur telur asin ayam ras dan telur asin itik adalah berbeda nyata artinya telur asin ayam lebih disukai dari pada telur asin itik dari segi tekstur. Hal ini disebabkan karena tekstur telur asin itik yang agak lunak karena pengaruh kadar air yang tinggi. Selain itu disebabkan karena pada telur asin itik memiliki kadar air yang tinggi sehingga konversi padatan (lemak) semakin menurun dalam telur, sehingga menyebabkan menurunnya cita rasa telur asin itik.

Bentuk suatu bahan ataupun produk akan menentukan tekstur dari bahan-bahan atau produk tersebut. Seimbangnya bentuk dengan padatan yang terkandung bahan atau produk akan menyebabkan tekstur bahan atau produk menjadih lebih baik (Marni, 2012).

\section{KESIMPULAN}

Berdasarkan hasil dari penelitian yang dilakukan dapat disimpulkan bahwasannya tingkat kesukaan konsumen terhadap telur asin ayam ras dan telur asin itik di Kecamatan Kembangbahu, Kabupaten Lamongan memberikan perbedaan yang nyata $\left(T_{\text {hitung }} \geq 0,5\right)$. Dari uji organoleptik (rasa, aroma/bau, warna dan tekstur) telur asin ayam ras lebih disukai dibandingkan telur asin itik.

\section{REFERENSI}

Badan Pusat Statistika Lamongan. 2017. Produksi Telur (kg) 2009-2013. https://lamongankab.bps.go.id/linkTabelStatis/view/id/302. diakses 01 Agustus 2017.

Budiman, A., A. Hintono dan Kusrahayu. 2012. Pengaruh Lama Penyangraian Telur Asin Setelah Perebusan Terhadap Kadar NaCl, Tingkat Keasinan dan Tingkat Kekenyalan. Animal Agriculture Journal, 1(2): 219-227.

Lesmayati, Susi. 2014. Pengaruh Lama Pemeraman Telur Asin Terhadap Tingkat Kesukaan Konsumen. Balai Pengkajian Teknologi Pertanian (BPTP). Kalimantan Selatan.

Lukito, G.A. 2012. Pengaruh Berbagai Metode Pengasinan Terhadap Kadar NaCl, Kekenyalan dan Tingkat Kesukaan Konsumen pada Telur Puyuh Asin. Skripsi. Fakultas Peternakan dan Pertanian, Universitas Diponegoro. Semarang.

Marni, Gusti. 2012. Pengaruh Konsentrasi Garam Terhadap Kadar Protein dan Kualitas Organoleptik Telur Puyuh Asin. Skripsi. Program Studi Pendidikan Biologi Sekolah Tinggi Keguruan Dan IImu Pendidikan (STKIP), PGRI Sumatera Barat.

Masykuroh, Hikmatun. 2016. Penentuan Umur Simpan Telur Asin yang Mengaplikasikan Asap Cair Tempurung Kelapa. Skripsi. Fakultas Teknik, Universitas Pasundan. Bandung.

Novia. 2011. Kajian Suhu Pengovenan Terhadap Kadar Protein dan Nilai Organoleptik Telur Asin. Jurnal Peternakan Vol 8No 2 September 2011 (70 - 76). Fakultas Peternakan, Universitas Andalas. Padang.

Nurhidayat, Y., J. Sumarmono dan S. Wasito. 2012. Kadar Air, Kemasiran dan Tekstur Telur Asin Ayam Niaga yang Dimasak dengan Cara Berbeda. Jurnal IImiah Peternakan, 1(3): 813-820.

Nuruzzakia. 2016. Pengaruh Konsentrasi Garam Terhadap Kadar Protein dan Kualitas Organoleptik Telur Bebek. Program Studi Pendidikan Biologi FKIP, Universitas Syiah Kuala. Aceh.

Putri. 2011. Pengaruh Penambahan Ekstrak Jahe (Zingiber officinale Roscoe) Terhadap Aktivitas Antioksidan, Total Fenol dan Karakteristik Sensoris pada Telur Asin. Skripsi. Fakultas Teknologi Hasil Pertanian, Universitas Sebelas Maret Surakarta. Surakarta.

Rukmiasih. 2015. Sifat Fisik, Kimia dan Organoleptik Telur Asin Melalui Penggaraman dengan Tekanan dan Konsentrasi Garam yang Berbeda. Skripsi. Fakultas Peternakan, Institut Pertanian Bogor. Bogor.

Sukma, A.W. 2012. Perubahan Mutu Hedonik Telur Asin Sangrai Selama Penyimpanan. Skripsi. Fakultas Peternakan dan Pertanian, Universitas Diponegoro. Semarang.

Utomo, Budi. 2006. Pengaruh Umur Telur Terhadap Kualitas Kemasiran Telur Asin yang Diasin Selama 14 Hari. Skripsi. Fakultas Peternakan, Institut Pertanian Bogor. Bogor.

Wulandari, Z., Y. Haryadi, dan P.S. Hadrjosworo. 2002. Sifat Organoleptik dan Karakteristik Mutu Telur Itik Asin Hasil Penggaraman dengan Tekanan. Media Peternakan. 25(1) : 7-13.

Zulaekah, S dan E. N. Widyaningsih. 2005. Pengaruh Konsentrasi Ekstrak Daun Teh pada Pembuatan Telur Asin Rebus Terhadap Jumlah Bakteri dan Daya Terimanya. Jurnal Penelitian Sains dan Teknologi. 6 (1):1-13. 